\title{
GERMINATIVE CELLS AND SPERMATOGENESIS OF THE LIZARD Tropidurus torquatus (Tropiduridae) FROM A URBAN AREA IN THE CERRADO BIOME OF THE BRAZILIAN MIDWEST
}

\author{
CÉLULAS GERMINATIVAS E ESPERMATOGÊNESE DO LAGARTO Tropidurus \\ torquatus (Tropiduridae) DE UMA ÁREA URBANA NO BIOMA CERRADO DO \\ CENTRO-OESTE BRASILEIRO
}

\section{Débora SILVA'; Mamynne RODRIGUES²; Mahmoud MEHANNA³; Adelina FERREIRA Heidi DOLDER ${ }^{5}$}

1. Doutoranda em Biologia Celular e Estrutural, Instituto de Biologia, Universidade Estadual de Campinas, Campinas - São Paulo, Brasil. debora.biocel@gmail.com; 2. Mestranda em Ecologia e Conservação da Biodiversidade, Instituto de Biociências, Universidade Federal de Mato Grosso, Cuiabá - Mato Grosso, Brasil; 3. Pós-Doutorado do Programa de Pós-Graduação em Ciências Ambientais, Universidade Federal de Rondônia, Rolim de Moura - Rondônia, Brasil; 4. Professor Adjunto do Departamento de Biologia e Zoologia, Instituto de Biociências, Universidade Federal de Mato Grosso, Cuiabá - Mato Grosso, Brasil; 5. Professor Titular do Departamento de Biologia Estrutural e Funcional, Instituto de Biologia, Universidade Estadual de Campinas, Campinas - São Paulo, Brasil.

\begin{abstract}
Tropidurus comprises a Neotropical genus of lizard that currently has about 30 species widely distributed in the South American. Among these species, Tropidurus torquatus, which has the characteristic of great physiological plasticity, occupying a variety of habitats in open areas and urbanized environments. Considering this, the aim of the study was to investigate the germinative cells and spermatogenesis of a population of T. torquatus in an urban area under Cerrado Biome influences to understand how to establish the temporal development of germinative cells and spermatogenesis during a period of one year. Individuals were obtained in the Zoological Collection of Vertebrates at the Universidade Federal de Mato Grosso (UFMT), and the germinative cells and full spermatogenesis were described with light microscopy. Tropidurus torquatus presented germ cells with similar characteristics already documented for the other species of lizards and reptiles. Spermatogonia type A and B, primary and secondary spermatocytes, and spermatids were present in almost all months evaluated. The gonadosomatic ratio presented its highest value in October, moment in which spermatogenesis presented all the germinative cells and spermatozoa in the lumen, of the seminiferous tubules. In the seasonal climate of the Cerrado Biome, we observe discontinuous spermatogenesis in T. torquatus with the production of spermatozoa in almost every month of the year, however with sperm storage in the epididymis during the phase of testicular regression.
\end{abstract}

KEYWORDS: Reproduction. Male lizard. Savanna. Brazil

\section{INTRODUCTION}

The adjustments involved in gametogenesis include, among others, morphological and functional differentiation of the organs related to the production and conducing of the gametes, fertilization and embryo development. In lizards, the temporal development of the germ cells is reflected in the testicular architecture (GRIBBS et al., 2003), allowing the definition of three types of reproduction: continuous reproduction (WILHOFT, 1963; INGER; GREENBERG, 1966), continuous with variation in spermatogenic activity (LICHT; GORMAN, 1970; SEXTON et al., 1971), and discontinuous or seasonal reproduction (LICHT; GORMAN, 1970; MARION; SEXTON, 1971). According to Ferreira; Dolder (2002), reproduction, histologically described, is considered continuous if all germ cell classes are present in the seminiferous tubules at different stages of spermatogenesis during all periods of the year. However, discontinuous reproduction is characterized by its opposite with periods of the year in which only primordial cells of spermatogenesis are observed, while in other periods, mature cells of spermatogenesis fill the entire lumen of the tubule (FERREIRA; DOLDER, 2002).

Tropidurus (WIED-NEUWIED, 1825) is a Neotropical genus of lizard with one of the widest distributions in the South American continent (CARVALHO, 2013). It is a lizard considered an early maturing animal, characterized by a short life expectancy and high fertility (TINKLE et al., 1970). Considering the wide geographic distribution of $T$. torquatus and its versatility to reproduce in different types of habitats, including urban areas.

The objective of this study was to evaluated the germinative cells and spermatogenesis of $T$. torquatus belonging to a population in the Cerrado Biome from urban area of the city Cuiabá, Mato Grosso state, Brazil. Additionally, comparison of spermatogenesis for the same species and its 
congeners from the other localities in South America was established.

\section{MATERIAL AND METHODS}

\section{Specimens and Climate Data}

For this study, male specimens of Tropidurus torquatus deposited in the Zoological Collection of Vertebrates of the Universidade Federal de Mato Grosso were used. According to the records, these specimens were collected monthly in a period from june/2012 to may/2013, on the campus of this university in the urban area of the
Cuiabá city, capital of Mato Grosso in the Brazilian Midwest (Fig. 1). This region in the Cerrado Biome is under the influence of tropical climate (Aw) following the KÖPPEN classification (1931), which is characterized by a seasonal precipitation, where rainfall is abundant for a period at the wet season and scarce in the dry season (SOUZA et al. 2013). To collect climate data, we considered the average monthly precipitation values, which were obtained by consulting the database of the Instituto Nacional de Pesquisas Espaciais (INPE) and the Centro de Previsão de Tempo e Estudos Climáticos (CPTEC).

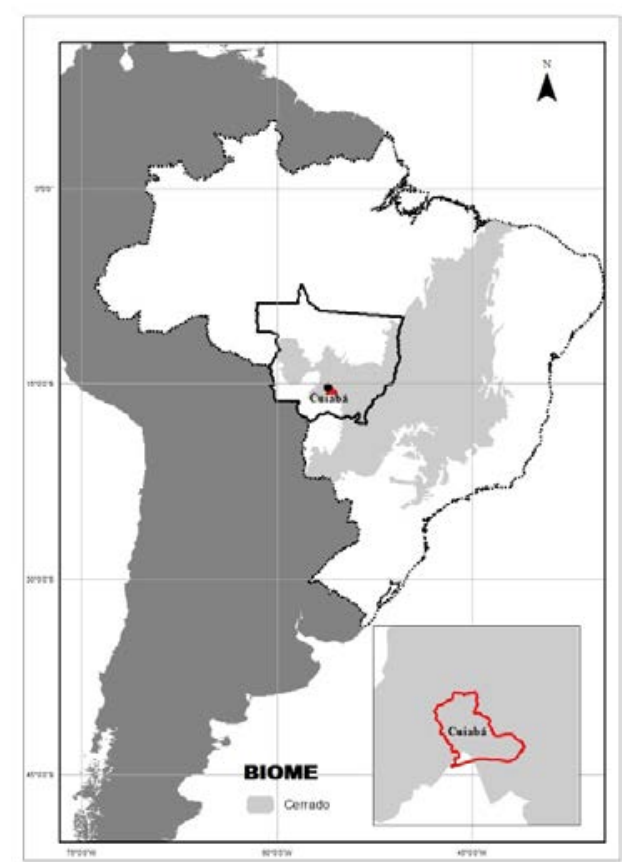

Figure 1. Map of the municipally of Cuiabá in Mato Grosso state, Brazil within the Cerrado Biome. Measurements and Light Microscopy

For evaluation of the specimens, we recorded the snout-vent length (SVL) with a digital caliper with an accuracy of $0.001 \mathrm{~mm}$. The gonadosomatic ratio (GR) was obtained using the ratio of the weight of the right testicle and the lizard weight for each individual sampled. After this evaluation, samples of the right testis and epididymis were submitted to a histological protocol adapted by FERREIRA et al. (2011), for light microscopy. Subsequently, the samples were embedded in methacrylate plastic resin and sectioned with $3 \mu \mathrm{m}$ thickness at intervals of $30 \mu \mathrm{m}$ between sections. The sections were stained with $1 \%$ toluidine blue ( $\mathrm{pH} 5 \sim 6$ ), totaling three sections for each sample from each individual. For photo documentation and histological analysis, a capture system coupled to the optical microscope with the software Leica Application Suite (LAS V.3) was used. All histological material was deposited in the Laboratory of Morphology of the Universidade Federal de Mato Grosso.

A qualitative approach was used to determine the occurrence and duration of spermatogenesis through the identification of the all germ cells, their occurrence and duration throughout the months of a year. The observation of only early germ cells and absence of spermatozoa in the seminiferous tubules and epididymis were considered to indicate a period with no reproductive individuals. 


\section{RESULTS}

\section{Specimens and Germinative Cells}

The total of 52 male lizards of Tropidurus torquatus were analyzed, having the average SVL of $102.03 \mathrm{~mm}( \pm 14.06)$. The testes were located in the dorsal region of the abdomen, occurring in pairs. The seminiferous tubules presented all types of germline cells (Figure 2A) during period of study. Spermatogonia type A was observed in the periphery of the seminiferous tubules, with an oval shape and poorly staining cytoplasm and the nucleus having an evident nucleolus (Figure 2A).
Spermatogonia type A go into mitosis, resulting in spermatogonia type B. Spermatogonia type B were also observed on the basal lamina of the tubule, but with a rounded shape, more strongly stained cytoplasm and the nucleus which may present a conspicuous nucleolus or aggregates of heterochromatin (Figure 2A). Both spermatogonia were present in the seminiferous tubules throughout the study period, but were more evident in the proliferation phase in the months of May and June, decreasing progressively until the phase of regression between february to march (Figure 2B).
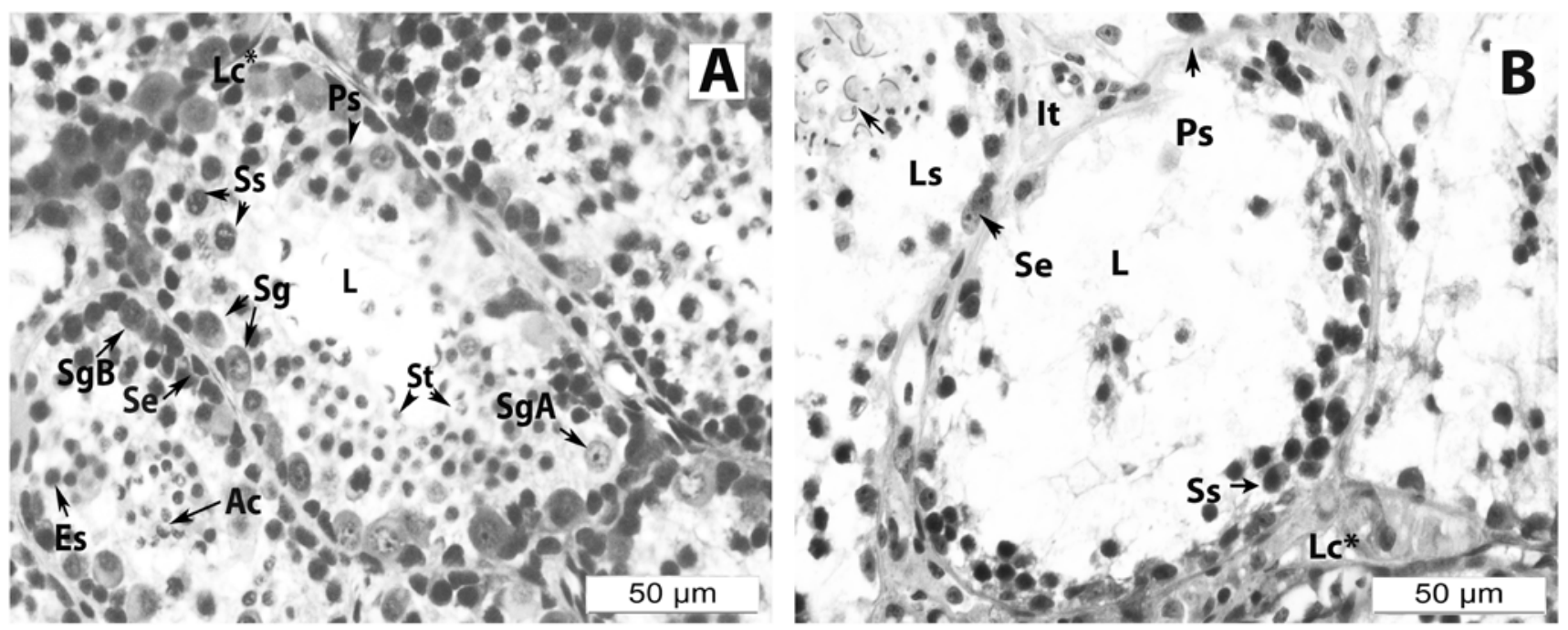

Figure 2. Light microscopy of the seminiferous tubules of the lizard Tropidurus torquatus during the study period in a locality of the urban area of the Cerrado Biome in the city of Cuiabá, Mato Grosso, Brazil. A - Seminiferous tubule with germinative cells and interstitial tissue during the testicular spermiation phase in July and B - during regression in march. Abbreviations: Sg = Spermatogonia; SgA = Spermatogonia A; SgB = Spermatogonia B; Ps = Primary spermatocytes; Ss = Secondary spermatocytes; $\mathrm{St}=$ Spermatids; Es = Early spermatids; $\mathrm{Ls}=$ Late spermatids; $\mathrm{L}=$ Lumen; Se = Sertoli cell; Lc* = Leydig cell, It $=$ Interstitial tissue and Ac=Acrosome vesicle.

The primary spermatocytes correspond to the cells that go into meiosis, originating from Spermatogonia type B. In morphology, these cells showed different characteristics of the nucleus along meiosis I (Figure 3A - C). The spermatocyte during the leptotene phase presented a more strongly stained nucleus with filamentous chromatin. During the zygotene phase the nucleus showed dense chromatin with the formation of small lumps, occupying the entire nuclear area. In pachytene, cells were larger with heavily stained nuclei, with little gaps being observed in the nucleoplasm (Figure 3A). In metaphase of meiosis I the alignment of homologous chromosomes was observed in the central region of the cell. Primary spermatocytes were observed during all months of the study, especially in the phases of proliferation and spermiation of $T$. torquatus (Figure $3 \mathrm{~A}-\mathrm{C}$ ). Secondary spermatocytes were a product of meiosis I, but they are difficult to visualize and differentiate from early spermatids. Secondary spermatocytes present the nucleus with more compacted chromatin, evident nucleolus and reduced cytoplasm in relation to primary spermatocytes (F Figure 3A, C). These spermatocytes were observed near the periphery of the seminiferous tubule when spermiation was reduced and close to the lumen when spermiation was more intense with release of mature spermatozoa (Figure 3B). 

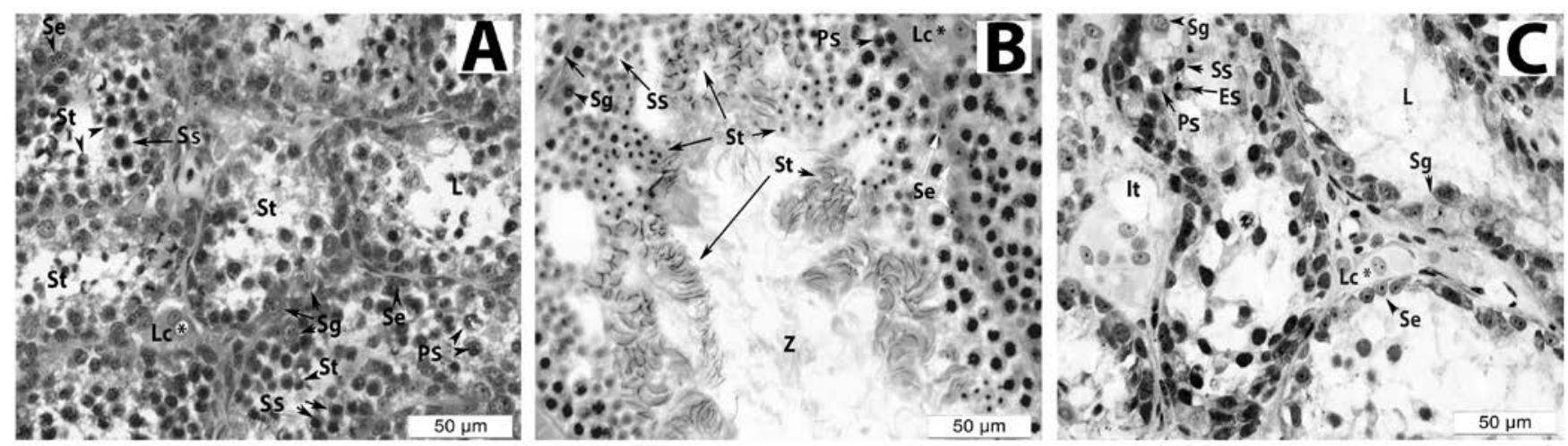

Figure 3. Light microscopy of the seminiferous tubules of the lizard Tropidurus torquatus during the study period in a locality of the urban area of the Cerrado Biome in the city of Cuiabá, Mato Grosso, Brazil. A - Seminiferous tubules in the spermiation phase during the spermatogenesis in June. B Seminiferous tubules during the peak of the spermiation in October. C - Seminiferous tubules during testicular regression with no spermatozoa in the tubule lumen in May. Abbreviations: $\mathrm{Sg}=$ Spermatogonia; Ps = Primary spermatocytes; Ss = Secondary spermatocytes; $S t=$ Spermatids; Es = Early spermatids; L = Lumen; Se = Sertoli cell; Lc* = Leydig cell; It = Interstitial tissue and Z = Spermatozoa.

Spermatids were present during the stages of spermiation and regression of spermatogenesis (Figure 3A - C) and have different structural characteristics during their maturation. We observed the initial spermatids or round spermatids with a strongly stained nucleus and strongly condensed chromatin (Figure 2A, 3B). The acrosome was observed as the formation of a blank space over the nucleus of spermatids (Figure 2A). Later, we observed the elongated spermatids with a thick dense filamentous shape surrounded by a less strongly stained cytoplasm (Figure 2A). Spermiation occurred in almost every month of the study period, decreasing in intensity during the regression phase, and ceasing in the months of February to April (Figure 3A-C).

\section{Spermatogenesis}

We observed that spermatogenesis was divided into four phases: proliferation, spermiation, regression, and quiescence. The proliferation phase starts in May, where the seminiferous tubules had spermatogonia and primary spermatocytes, which subsequently produced the first spermatids (Figure 3A). During June to February the spermiation phase was characterized by a high germinal epithelium with many layers of cells, and in most of them secondary spermatocytes and spermatids can be found (Figure 3B). With increasing intensity of spermatogenesis, many spermatids changed their structure, completing maturation with the progressive release of spermatozoa in the lumen of the tubules (Figure 3B). The regression phase was observed during February to April, and is characterized by diminishing layers of germ cells, detachment of part of the germinal epithelium and emptying lumens (Figure 2B, 3C). In this phase, spermatozoa were rarely visualized in the lumen of the seminiferous tubules, being stored in the epididymis. The quiescent phase was brief, occurring in April and a few individuals possessed tubules with only two cell types, spermatogonia and Sertoli cells, that reorganized the testicular architecture for next proliferation phase.

The epididymis showed structural changes in the epithelium and in its production of secretion during spermatogenesis of Tropidurus torquatus. During spermiation phase, the epithelium showed hypertrophy with tall cells and many secretory vesicles observed in the cytoplasm during the months of June to January (Figure 4 A). Spermatozoa were observed in the epididymis lumen in the same period (Figure $4 \mathrm{~A}$ ). In the months of February to April, during the phase of testicular regression, the epithelium of the epididymis decreased in height, with few vesicles observed in the cytoplasm of epithelial cells (Figure $4 \mathrm{~B}$ ). The complete absence of spermatozoa in the lumen of the epididymis was observed only in April.

The gonadosomatic ratio showed variations over the months of study, reaching the highest value in October when spermatogenesis presented all the germinative cells, mostly spermatids and spermatozoa in the lumen (Figure 5). However, after December the gonadosomatic ratio decreased progressively, following the changes in the arrangements of germinative cells that decrease in quantity, leading to the regression phase of the 
spermatogenesis (F Figure 5). The lowest value of the index occurred in May, where the tubule remains empty without spermatozoa in the lumen (Figure 5).
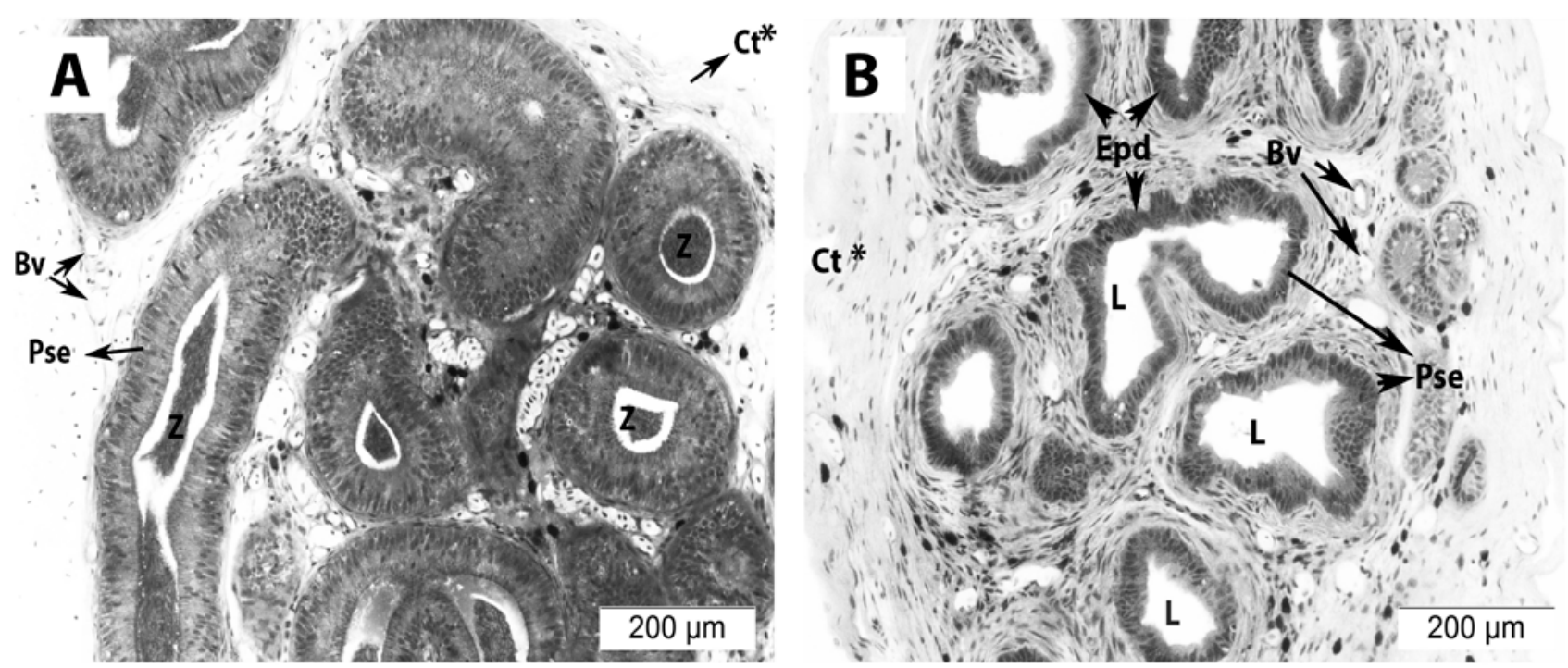

Figure 4. Light microscopy of the epididymis of the lizard Tropidurus torquatus from the urban area of the Cerrado Biome in the city of Cuiabá, Mato Grosso, Brazil. A - Period with reproduction demonstrated by the presence of free spermatozoa in the lumen of the epididymis from July to January. B - Period without reproduction shown by the absence of spermatozoa in the lumen of the epididymis in April. Abbreviations: $\mathrm{Ct}^{*}=$ Conjunctive tissue; Epd $=$ Epididymis; Pse $=$ Pseudostratified columnar epithelium; $\mathrm{Z}=$ Spermatozoa; $\mathrm{Bv}=$ Blood vessels and $\mathrm{L}=$ Lumen.

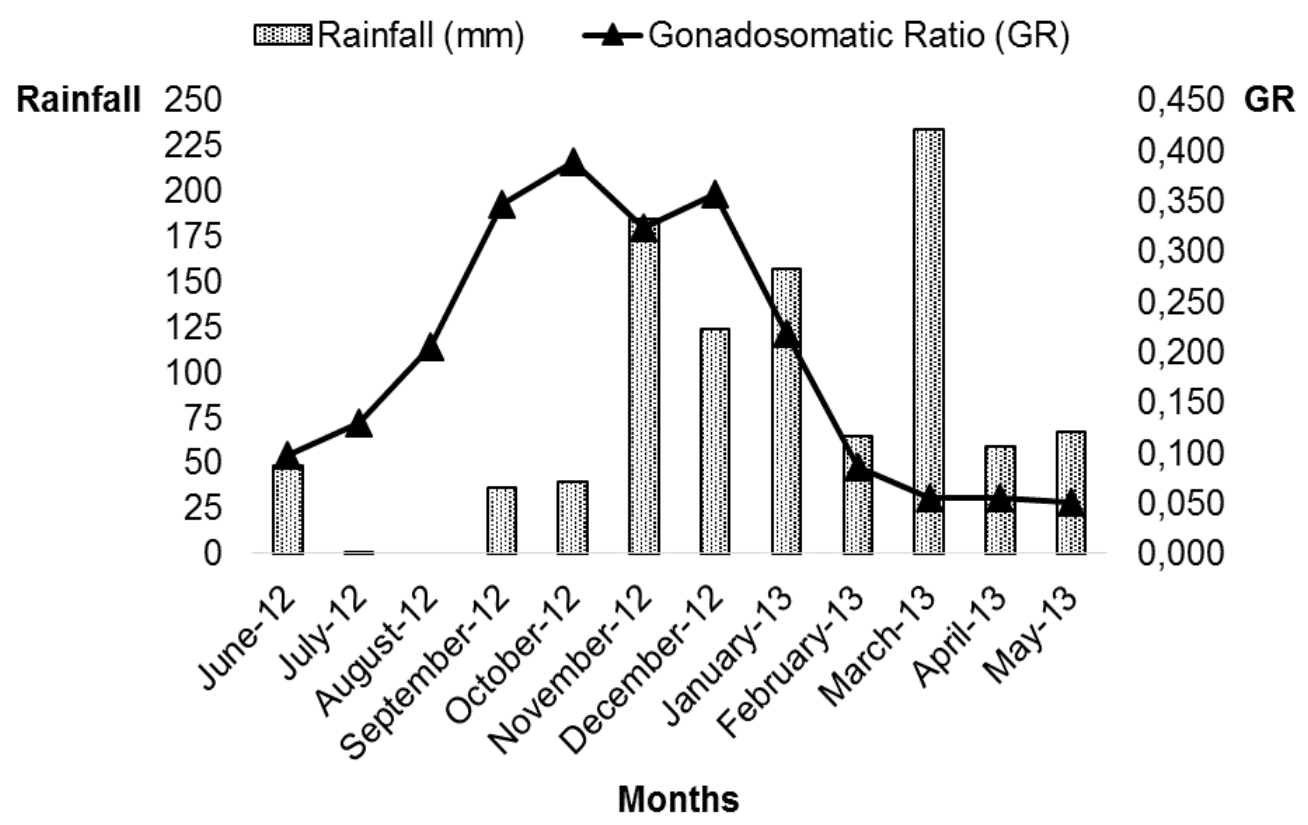

Figure 5. Distribution of values of the gonadosomatic ratio (GR) for the lizard Tropidurus torquatus from the Cerrado Biome in the urban area in the city of Cuiabá, Mato Grosso, Brazil. The values correspond the period of June/2012 to May/2013, which was calculated for all individuals and the average values distributed for each month.

\section{DISCUSSION}

We evaluated the development of germinative cells in the lizard Tropidurus torquatus during the period of one year. Significant morphological differences and changes in the testicular architecture were identified during spermatogenesis the spermatogonia observed were 
identified as type A when had an oval shape and evident nucleolus, while the type B were lower with rounded shape and had heterochromatin aggregates in the nucleus. The same types of spermatogonia were identified in the lizard Podarcis muralis (GRIBBINS; GIST, 2003), as the permanent cells of tubules during all spermatogenic phases. In the lizard Mabuya brachypoda the spermatogonia type A had the same oval shape, but with one or two prominent nucleoli (HERNÁNDEZ-FRANYUTTI; URIBE, 2012), while in T. torquatus we observed only one nucleolus. In addition, in Sceloporus bicanthalis, spermatogonia type A with a clear nucleolus or sometimes the absence of a nucleolus were found (GRIBBINS, 2011). Despite the diversity in the presence and quantity of nucleoli of spermatogonia, the other germinative cells observed in $T$. torquatu, such as primary spermatocytes, secondary spermatocytes and spermatids were similar to the characteristics described in other cell types of different species of lizards (GRIBBINS; GIST, 2003; GRIBBINS, 2011; HERNÁNDEZFRANYUTTI; URIBE, 2012).

The analysis of germinative cells showed that spermatogenesis in Tropidurus torquatus had a discontinuous pattern, however with presence of spermatozoa in the seminiferous tubules and epididymis occurred almost every month of the year except in April. Previous studies with males of the $T$. torquatus species showed continued spermatogenesis in different Biomes and phytophysiognomies like as Caatinga (VITT; GOLDBERG, 1983), Cerrado (WIEDERHECKER et al., 2002), Pampa (ARRUDA, 2009), Restinga (VAN SLUYS et al., 2010), Atlantic Forest (GOMIDES et al., 2013), and Chaco (ORTIZ et al., 2014). These studies showed continuous production of spermatozoa for $T$. torquatus, but clearly decreased reproductive activity in the months of January to April, period in which we observed testicular regression in our study. The only exception was observed in the population of the Atlantic forest, which maintained the reproductive activity without variations between seasons. This demonstrates that spermatogenesis in T. torquatus can occur regardless of seasonal variations, the rainy and dry season being the extremes of these variations in Brazil. According to WIEDERHECKER et al. (2002), the continuous production of spermatozoa does not require high energy expenditure, and may be a consequence of the high hormone levels needed for territorialism activities. All the locations cited above, are near urban areas or areas with some kind of anthropic activity, such as pastures, fishing or housing. Thus, the comparison of our results with those of other studies mentioned above occurs under similar conditions of human influence.

We compared variation in spermatogenesis for the congeners of Tropidurus torquatus. For example, $T$. hispidus was presented as having continuous spermiation in the Caatinga Biome (RIBEIRO et al., 2012), but the spermiation was restricted from March to August in the Amazon Forest (PRIETO et al., 1976). The species T. itambere was considered reproductive throughout the year in the Atlantic Forest (VAN SLUYS, 1993). However, the relationship between the types of germinative cells and the size of seminiferous tubules showed differences of spermatogenic activity, with all types of germinative cells present, but with regression during February to April (FERREIRA et al., 2009). For T. oreadicus from the Cerrado Biome, spermatogenesis was more intense during the months of June to September, during the dry season (MEIRA et al., 2007; FERREIRA et al., 2011). Another species of the Cerrado, T. montanus, presented reproductive males throughout the year, but in greater proportion from September to January (VAN SLUYS et al., 2002). Lizards of the genus Tropidurus have spermatogenesis that can be characterized as continuous, seasonal or discontinuous, depending on the aspect considered. Some species have continuous production of spermatozoa, despite the decrease in testicular parameters (e.g. T. torquatus, WIEDERHECKER et al., 2002; ORTIZ et al., 2014). Others have a seasonal reproduction, concentrating spermatogenesis in a specific period, such as $T$. itambere and T. hispidus (VAN SLUYS et al., 1993; RIBEIRO et al., 2012). Alternatively, they can be seasonal with interruption of spermatogenesis as observed in our study and in T. torquatus in the Restinga (VAN SLUYS et al., 2010).

Thus reproductive studies also should consider the development of germinative cells, which is the most appropriate way to explain during which period the species is able to reproduce and how it can change over time. The presence of spermatozoa in the lumen of the tubules and epididymis is a strong indicator of reproductive fitness, and the analysis of all types of germinative cells is also important to detect a regression stage, which can interrupt, or not, the progression of spermatogenesis.

\section{CONCLUSIONS}

This population of male lizards of Tropidurus torquatus, inhabiting an urban area of 
the city of Cuiabá under influences of the Cerrado Biome, presented all the types of germinative cells with morphologic and structural similarities to other species of lizards and other reptiles.

Spermatogenesis occurred in the almost all months in the year, but spermiation was discontinuous with a brief period for testicular regression.

The epididymis presented structural variation of the epithelium during spermiation and testicular regression, the storage of spermatozoa being observed even when the tubules had empty lumen. These results are, in part, similar to another population of $T$. torquatus from the Cerrado Biome. However, there is a limited number of descriptive studies of germinative cells and spermatogenesis for the other populations of this species in Brazil.

\section{ACKNOWLEDGEMENTS}

We are grateful to CNPq for the support provided by the grant of scientific initiation (Process number 101695/2007-1); to Felipe F. Curcio curator of the Zoological Collection of Vertebrates of the Universidade Federal de Mato Grosso (UFMT-R), and Mr. Evanildo Albuquerque for giving the workspace and access to the specimens used in this study. We also thank Laura Garcia for helping us with detailing the map, and the author Mahmoud Mehanna wishes to thank CAPES for financial support.

RESUMO: O gênero de lagartos neotropicais Tropidurus tem cerca de 30 espécies amplamente distribuídas no continente sul-americano. Entre essas espécies, Tropidurus torquatus é a que apresenta grande plasticidade fisiológica, ocupando uma variedade de hábitats em áreas abertas e ambientes urbanizados. Considerando isso, o objetivo do estudo foi investigar as células germinativas e a espermatogênese de uma população de T. torquatus em uma área urbana sob a influência do Bioma Cerrado para entender como é estabelecido o desenvolvimento temporal das células germinativas e a espermatogênese durante o período de um ano. Indivíduos foram obtidos na Coleção Zoológica de Vertebrados da Universidade Federal de Mato Grosso (UFMT). A caracterização das células germinativas e da espermatogênese foi realizada através de microscopia de luz. Tropidurus torquatus apresentou células germinativas com características similares às já documentadas para outras espécies de lagartos e répteis. Espermatogônias do tipo $\mathrm{A}$ e $\mathrm{B}$, espermatócitos primários e secundários e espermátides estiveram presentes praticamente em todos os meses. A razão gonadossomática apresentou seu valor máximo em outubro, momento em que a espermatogênese apresentou todas as células germinativas e espermatozoides no lúmen do túbulo seminífero. No clima sazonal do Bioma Cerrado observamos espermatogênese descontínua em $T$. torquatus com a produção de espermatozoides em quase todos os meses do ano, porém com estocagem nos epidídimos durante a fase de regressão testicular.

PALAVRAS-CHAVE: Reprodução. Lagarto macho. Savana. Brasil.

\section{REFERENCES}

ARRUDA, J. L. S. Ecologia de Tropidurus torquatus (Squamata:Tropiduridae) no bioma Pampa, extremo sul do Brasil. Santa Maria, RS: 2009. Originalmente apresentada como dissertação de mestrado, Universidade Federal de Santa Maria, 2009.

CARVALHO, A. L. G. On the distribution and conservation of the South American lizards genus Tropidurus Wied-Neuwied, 1825 (Squamata:Tropiduridae). Zootaxa, New Zealand, v. 3640, n. 1, p. 042-056, 2013. http://dx.doi.org/10.11646/zootaxa.3640.1.3.

FERREIRA, A.; DOLDER, H. Ultrastructural analysis of spermiogenesis in Iguana iguana (Reptilia: Sauria: Iguanidae). Eur. J. Morphol, Netherlands, v. 40, n. 2, p. 89-99, 2002.

FERREIRA, A.; SILVA, D.N.; VAN SLUYS, M.; DOLDER, H. Seasonal changes in testicular and epididymal histology of the tropical lizard, Tropidurus itambere (Rodrigues, 1987), during its reproductive cycle. Braz. J. Biol, Brazil, v. 69, n. 2, p. 429-435, 2009. http://dx.doi.org/10.1590/S1519-69842009000200028.

FERREIRA, A.; KIHARA, V. O.; MEHANNA, M. Reproductive strategies of brazilian lizards of the genus Tropidurus Rodrigues, 1987 (Squamata, Tropiduridae) in temporal and spatial. Int. J.Morphol, Chile, v. 29, n. 4, p. 1414-1421, 2011. http://dx.doi.org/10.4067/S0717-95022011000400058. 
GOMIDES, S. C.; RIBEIRO, L. B.; PETERS, V. M.; SOUSA, B. M. Feeding and reproduction ecology of the lizard Tropidurus torquatus (Squamata: Tropiduridae) in a rock outcrop area in southeastern Brazil. Rev.Chil. Hist. Nat, v. 86, n. 2, p. 137-151, 2013. http://dx.doi.org/10.4067/S0716-078X2013000200003.

GRIBBS, K. M.; GIST, D. H. Cytological evaluation of spermatogenesis within the germinal epithelium of the male European wall lizard, Podarcis muralis. J. Morphol, v. 258, n. 3, p. 296-306, 2003.

http://dx.doi.org/10.1002/jmor.10143.

GRIBBS, K. M. Reptilian spermatogenesis: a histological and ultrastructural perspective. Spermatogenesis, v. 1, n. 3, p. 250-269, 2011. http://dx.doi.org/10.4161/spmg.1.3.18092.

HERNÁDEZ-FRANYUTTI, A.; URIBE, M. C. Seasonal spermatogenic cycle and morphology of germ cells in the viviparous lizard Mabuya brachypoda (Squamata, Scincidae). J. Morphol. v. 273, n. 11, p. 1199-1213, 2012. http://dx.doi.org/10.1002/jmor.20050.

INGER, R. F.; GREENBERG, B.. Ecological and competitive relations among three species of frog (genus Rana). Ecology, v. 47, n. 5, p. 746-759, 1966. http://dx.doi.org/10.2307/1934261.

KÖPPEN, W. Grundriss der klimakunde: outline of climate science. Berlin: Walter de Gruyter, 1931, 388p.

LICHT, P.; GORMAN, G. C. Reproductive and fat cycles in Caribbean Anolis lizards. Uni. California Public. California, v. 95, n. 23, p. 1-52, 1970.

MARION, K. R.; SEXTON, O. J. The reproductive cycle of the lizard. Sceloporus malachiticus in Costa Rica. Copeia, Miami, v. 1971, n. 3, p. 517 - 526, 1971. http://dx.doi.org/10.2307/1442449.

MEIRA, K. T. R.; FARIA, R. G.; SILVA, M. D. M.; MIRANDA, V. T.; ZAHN-SILVA, W. História natural de Tropidurus oreadicus em uma área de cerrado rupestre do Brasil Central. Biota Neotrop. São Paulo, v. 7, n. 2, p. 155-163, 2007.

ORTIZ, M. A.; BORETTO, J. M.; PIANTONI, C.; ÁLVAREZ, B. B.; IBARGUENGOTÍA, N. R. Reproductive biology of the Amazon lava lizard (Tropidurus torquatus) from the wet Chaco of Corrientes (Argentina): congeneric comparisons of ecotypic and interspecific variations. Can. J. Zool. v. 92, n. 7, p. 643655, 2014. http://dx.doi.org/10.1139/cjz-2014-0002.

PRIETO, A. S.; LEON, J.R.; LARA, O. Reproduction in the tropical lizard, Tropidurus hispidus (Sauria: Iguanidae). Herpetol, v. 32, n. 3, p. 318-323, 1976.

RIBEIRO, L. B.; SILVA, N. B.; FREIRE, E. M. X. Reproductive and fat body cycles of Tropidurus hispidus and Tropidurus semitaeniatus (Squamata, Tropiduridae) in a caatinga area of northeastern Brazil. Rev.Chil. Hist. Nat. Santiago, v. 85, n. 3, p. 307-320, 2012. http://dx.doi.org/10.4067/S0716-078X2012000300005.

RODRIGUES, M. T. Sistemática, ecologia e zoogeografia dos Tropidurus do Grupo Torquatus ao sul do rio Amazonas (Sauria, Iguanidae). Arq. Zool. Mus. Zool. USP, São Paulo, v. 31, n. 3, p.105-230, 1987. http://dx.doi.org/10.11606/issn.2176-7793.v31i3p105-230.

RUIBAL, R.; PHILIBOSIAN, R.; ADKINS, J. L. Reproductive cycle and growth in the lizard Anolis acutus. Copeia, Miami, v. 1972, n. 3, p.509-518, 1972. http://dx.doi.org/10.2307/1442923.

SEXTON, O. J.; ORTLEB, P.; HATHAWAY, M.; BALLINGUER, R. E.; LICHT, P. Reproductive cycles of three species of anoline lizards from the Isthmus of Panama. Ecology, Washington, v. 52, n. 2, p. 201-215, 1971. http://dx.doi.org/10.2307/1934579. 
SOUZA, A. P.; MOTA, L. L.; ZAMADEI, T.; MARTIN, C. C.; ALMEIDA F. T.; PAULINO, J. Classificação climática e balanço hídrico climatológico no estado de Mato Grosso. Nativa, Sinop, v. 1, n. 1, p.34-43, 2013.

TINKLE, D. W.; WILBUR, H. M.; TILLEY, S. G. Evolutionary strategies in lizard reproduction. Evolution. Missouri, v. 24, n. 1, p. 55-74, 1970. http://dx.doi.org/10.2307/2406714.

VAN SLUYS, M. The reproductive cycle of Tropidurus itambere (Sauria: Tropiduridae) in southeastern Brazil. J. Herpetol. Kansas, v. 27, n. 1, p. 28-32, 1993. http://dx.doi.org/10.2307/1564901.

VAN SLUYS, M.; MENDES, H. M. A.; ASSIS, V. B.; KIEFER, M. C. Reproduction of Tropidurus montanus Rodrigues, 1987 (Tropiduridae), a lizard from a seasonal habitat of southeastern Brazil, and a comparison with other Tropidurus species. Herpetol. J. United Kingdon, v. 12, n. 3, p. 89-97, 2002.

VAN-SLUYS, M.; MARTELOTTE, S. B.; KIEFER, M. C.; ROCHA, C. F. D. Reproduction in neotropical Tropidurus lizards (Tropiduridae): evaluating the effect of environmental factors on T. torquatus. Amph.Reptilia. Boston, v. 31, n. 1, p. 117-126, 2010. http://dx.doi.org/10.1163/156853810790457920.

VITT, L. J.; GOLDBERG, S. R. Reproductive ecology of two tropical iguanid lizards: Tropidrus torquatus and Platynotus semitaeniatus. Copeia, Miami, v. 1983, n. 1, p. 131-141, 1983. http://dx.doi.org/10.2307/1444707.

WIEDERHECKER, H. C.; PINTO, A. C. S.; COLLI, G. R. Reproductive ecology of Tropidurus torquatus (Squamata: Tropiduridae) in the highly seasonal Cerrado biome of central Brazil. J. Herpetol. Kansas, v. 36, n. 1, p. 82-91, 2002. http://dx.doi.org/10.2307/1565806

WILHOFT, D. C. Gonadal histology and seasonal changes in the tropical Australian lizard, Leiolopisma rhomboidalis. J. Morphol. United States, v. 113, p. 185-203, 1963. 